\title{
Ismar Tirelli Neto e as vias da extinção
}

\author{
Ismar Tirelli Neto and the paths of instinction \\ Ismar Tirelli Neto y las vías de la extinción
}

Carolina Anglada*

\section{Resumo}

Este artigo busca ler a poética do escritor brasileiro Ismar Tirelli Neto em seus movimentos desassossegados de retorno, deambulação e desvio, que acabam por dessituar a própria noção de lugar (da memória, da poesia, das imagens) e do ter lugar da linguagem. Nesse caso, o intuito é analisar como a sua voz procura se encontrar à deriva, nos confins da linguagem, tornando-se irreconhecível em meio às incontáveis referências de cidades, bairros, cinemas, autores, muitos deles despercebidos, menores ou desaparecidos. Assim, intentamos dar a ver como certa poesia brasileira, em diálogo com toda uma tradição latino-americana ilhada, faz experiência dessa ausência de norte, mobilizando concepções fora de lugar e contribuindo sobremaneira para as relações entre literatura e política.

Palavras-chave: poesia contemporânea, poesia brasileira, Ismar Tirelli Neto.

\section{Abstract}

This article seeks to read the poetry of the Brazilian writer Ismar Tirelli Neto in his restless movements of return, ambulation and deviation, that end up undermining the very notion of place (of memory, of poetry, of images) and of language's possession of place. In this case, the intention is to analyze how his voice seeks to find himself adrift, becoming unrecognizable amid the countless references to cities, neighborhoods, cinemas, authors, many of them unnoticed, minor or missing. Thus, we try to show how a certain Brazilian poetry, in dialogue with an entire Latin American tradition, experiences disorientation, mobilizing out-ofplace concepts, and contributing to the relations between literature and politics.

Keywords: contemporary poetry, Brazilian poetry, Ismar Tirelli Neto.

\section{Resumen}

En este artículo busca leer la poética del escritor brasileño Ismar Tirelli Neto en sus movimientos desasosegados de retorno, deambulación y desvío, que acaban por desituar la propia noción de lugar (de la memoria, de la poesía, de las imágenes) y del tener lugar del lenguaje. En este caso, el propósito es analizar cómo su voz busca encontrarse a la deriva, haciéndose irreconocible en medio de las incontables referencias de ciudades, barrios, cines, autores, muchos de ellos inadaptados, menores o desaparecidos. Así, intentamos dar a ver cómo cierta poesía brasileña, en diálogo con toda una tradición latinoamericana aislada, hace experiencia de esa ausencia de norte, movilizando concepciones fuera de lugar, y contribuyendo em extremo a las relaciones entre literatura y política.

Palabras-clave: poesía contemporânea, poesía brasileña, Ismar Tirelli Neto.

está em uma ilha um teste de solidão

(Marília Garcia, engano geográfico)

\footnotetext{
* Doutora em Literaturas Modernas e Contemporâneas e professora da Universidade Federal de Ouro Preto (UFOP), Ouro Preto, MG, Brasil. Dorcid.org/0000-0003-3930-2893 E-mail: angladacarolina@ gmail.com
} 


\section{Recuperar o sentido de lugar}

Um livro pode encerrar um autor, pode encerrar uma matéria, pode encerrar-se em si mesmo. Mas um livro pode também esconder um arquipélago, que, por desejo ou sem tomar conhecimento, acaba sendo formado pelo desenho complexo que se traça entre obras de um mesmo autor ou através de questões que interpelam comparativamente tempos, lugares e escritas distintas. Ismar Tirelli Neto, escritor, roteirista e tradutor brasileiro, é um desses autores cuja obra possui um andamento muito peculiar, atravessando paisagens e personagens que ora nos permite traçar conexões, ora nos lança no mais profundo isolamento. Diante dessa movimentação, a nós cabe também mudarmos de posição, demorarmo-nos na visitação, para compreendermos as múltiplas camadas que, flutuando, se nos apresentam de modo intrincado, labiríntico, indireto.

Até hoje, Tirelli Neto já publicou cinco obras de poesia, que, em maior ou menor grau, questionam sobre as distâncias que separam (e ligam) os sujeitos e refazem os traçados de seus afetos, imagens e memórias, encenando, no verso, os muitos modos de sentir os desencontros que nos fundam. Por esse motivo, desde Synchronoscopio (2008), sua publicação de estreia, a poesia parece revelar sua qualidade de máquina cuja função seria medir as frequências de fontes alternadas de energia, isto é, de identificar as condições de uma sincronização específica. Paradoxalmente, a questão que parece se colocar de diferentes maneiras tem a ver com a complexa arquitetura das desorientações, das substituições e dos esquecimentos que assolam o sujeito contemporâneo, com interferências, então, na máquina poética que vem a falhar, mas falhar elegantemente, com humor. Escreve o poeta: "em represália, dou a cada dor antiga o nome de um / comediante // (Buster Keaton me pegou pelas canelas ontem à noite)" (Tirelli Neto, 2008, p. 41).

Tirelli Neto responde ao estado desolador da condição humana com graça e refinamento, sem que essa precisão que experienciamos por meio de sua dicção seja garantia de segurança. A linguagem escolhida, meticulosamente trabalhada, é senão a arma utilizada em represália ao próprio desalento que é perceber-se enquanto ser de linguagem. Quando aportamos a Os ilhados (2015), seu terceiro livro de poemas, composto também por textos prosaicos, o poeta nos recebe naquele espaço que também já não lhe pertence, e no qual não se reconhece: "Não sinto a menor falta do campo" (Tirelli Neto, 2015, p. 9). Esse retorno que se realizará sobre imagens do passado ou sobre o passado zeloso da linguagem não se fará mediante uma pulsão saudosista. Retorna-se, dá-se um passo atrás, escreve-se com tamanha polidez, não para recuperar o tempo perdido, mas para melhor desconhecer-se diante daquilo que também se apresenta deslocado. Trata-se de uma estratégia poética, mas também política diante de uma condição que insiste em se desfamiliarizar, em se colocar como indesejada.

A rigor, nesse primeiro texto, encontramos uma espécie de anúncio do que nos guiará: "toda terra é estrangeira para alguém" (Tirelli Neto, 2015, p. 9). E o mais difícil, segundo o poeta, não seria constatar, mas criar essa entrangeiridade constitutiva, arquitetar sua engrenagem, de modo que adviria daí uma "segunda natureza" (Tirelli Neto, 2015, p. 9), nunca uma origem localizável, um lugar de acolhimento. Assim, o poeta se dirige a temas que nos são sensíveis, mas que em outro sentido também o foram para épocas anteriores, mostrando que é necessário reconhecermos como as nossas raízes e os nossos costumes serão sempre irreconhecíveis para alguém. $\mathrm{E}$ a terra desse alguém, por sua vez, não será jamais nossa terra, se é que alguém ainda consegue se ver pertencendo acriticamente a algum espaço. Aceitar essa imperfeição na junção entre as origens e os sujeitos que dali emergem pode tanto gerar ilhas e apartamentos, quanto arquipélagos e coletivos.

Sob um título cujo sentido aponta para um amontoado de terra- que abarca tanto a ideia de flutuação quanto de isolamento -, a obra já promove paradoxalmente alguns diálogos possíveis, apesar de sua pretensa solidão. Sabemos que essa imagem tem longa e profunda repercussão na literatura, incluindo a Ítaca de Ulisses e a Ilha dos Amores de Camões, que marcaram e foram marcadas tão profundamente pelo imaginário dos viajantes, dos errantes e dos descobridores. Mas ainda sob esse pretexto, lembramos de uma obra ainda mais afim às questões que aqui propomos, sobretudo por sua raiz latino-americana: A invenção de Morel, de Adolfo Bioy Casares, narra a história de um escritor venezuelano, condenado à prisão perpétua, que, em uma fuga, exila-se em uma ilha, a qual descobre ser habitada por outros ilhados. Paulatinamente, o espaço 
outrora despovoado passa a ser palco de uma série de encontros, intrigas e mistérios provocados por esses outros personagens, também tratados como possíveis projeções ou fantasmagorias do imaginário do narrador. Diante de tamanha solidão, indaga-se se esses seres, assim como a própria ilha, não seriam fruto de seu pensamento ou de uma falta de lógica narrativa:

Fazia muito tempo que eu vinha pensando nisso, portanto já estava um pouco farto e continuei com menos lógica: não estive morto até os intrusos aparecerem; na solidão é impossível estar morto. Para ressuscitar, devo suprimir as testemunhar. Será um extermínio fácil. Eu não existo: não suspeitarão de seu aniquilamento (Casares, 2016, p. 59).

Casares, nessa obra escrita ainda em 1936, consegue antecipar muito do que viria a constituirse como a literatura fantástica, ao projetar essa espécie de máquina, construída mise en abyme pelo personagem Morel, que reproduziria infinitamente as imagens filmadas desses habitantes, no presente já mortos. Ao mesmo tempo, por trazer em notas de rodapé interferências de um pretenso editor, elabora-se um pensamento metalinguístico sobre o sistema precário e fantasioso da obra. A obra dialoga com a obra assim como os fantasmas comunicam-se entre si. Desse modo, perguntamo-nos, afinal, quais são os interlocutores da prosa e da poesia latino-americanas? Quando nossas obras conversam, com quem elas se sincronizam? Como sair desta zona isolada, cuja arquitetura fora desde o início inventada, rascunhada, idealizada pelos colonizadores, e banhada de água por todos os lados para não caber senão o idílico?

Se um sincronoscópio trabalha pelo equilíbrio entre picos positivos e negativos, é porque a relação entre as fontes tende a se alternar. Entre ser eu e ser outro, hesitou toda a nossa literatura de formação, criando uma espécie de condição labiríntica, comparada àquela formulação de Adorno, para quem "a referência ao social não deve levar para fora da obra de arte, mas sim levar mais fundo para dentro dela" (2003, p. 66). Octavio Paz, em seu El laberinto de la soledad, discorre precisamente sobre esse paradigma, mas tendo em vista nossa condição particular de latino-americanos, a partir da leitura do historiador mexicano Edmundo O'Gorman, autor de uma obra curiosamente intitulada A invenção da América:

O problema que preocupa O'Gorman é saber que tipo de ser histórico é o que chamamos América. Não é uma região geográfica, também não um passado e, talvez, nem sequer um presente. É uma ideia, uma invenção do espírito europeu. A América é uma utopia, isto, é o momento em que o espírito europeu se universaliza, desprende-se de suas particularidades históricas e concebe-se a si mesmo como uma ideia universal que, quase milagrosamente, encarna e se fixa numa terra e num tempo preciso: o futuro (Paz, 1950/1992, p. 151).

Sabemos que esse motivo nos circunda e nos funda, haja vista sua operação no pensamento de tantos intelectuais, inclusive brasileiros, como Euclides da Cunha, Roberto Schwarz, Luiz Costa Lima. A rigor, essa invenção chamada América Latina, fruto de um desejo, antes do que tudo, precisou reaver-se com o controle do imaginário ${ }^{1}$ operado pelas colônias para inventar também uma literatura que pudesse ocupar essa segunda natureza, representando as ideias e sentimentos políticos e sociais do povo das jovens nações. Muitas vezes, os impasses vividos politicamente ao longo dos séculos XVIII e XIX, eram sentidos também na forma de impasses amorosos, como o enamoramento do narrador pela personagem Faustine, de $A$ invenção de Morel (1936/2016), que, em várias camadas, trata do paradoxo entre o silêncio e a expressão, o próprio e o impróprio, a imaginação e a realidade. Assim ele declara:

Estar em uma ilha habitada por fantasmas artificiais era o mais insuportável dos pesadelos; estar apaixonado por uma dessas imagens era pior do que estar apaixonado por um fantasma (talvez sempre desejamos que a pessoa amada tenha uma existência de fantasma) (Casares, 2016, p. 81).

Para além de todo esse imaginário do amor que só se mantém através das imagens, presente em maior ou menor grau em muitas culturas e produções como as canções provençais (Agamben,

\footnotetext{
${ }^{1}$ A expressão é de Luiz Costa Lima, em obra homônima, na qual analisa os contextos de criseem que o controle recai sobretudo sobre o romance, haja vista o poder de seu agenciamento em estabelecer relações entre as enunciações, os imaginários e os sujeitos. Nesse caso, nós a utilizamos com o intuito de dar a ver certa fiscalização dos discursos e do que através deles pode ser dito, sentido e pensado.
} 
2007), o caso da América-Latina, ao qual o Brasil conflituosamente inclui-se excluindo-se, soma um nível a mais ao problema do acesso e da representação do real. Em um ensaio sobre os impasses de formalização, ${ }^{2}$ Raul Antelo, ao citar trecho da carta de um capitão e governador da Capitania de Pernambuco, sinaliza como a poesia, por sua proximidade com o desenho, nasce no Brasil como rascunho (Antelo, 2016, p. 98). Alguma coisa no excesso da luz tropical nos impossibilitaria de enxergar para além das fronteiras da ilha, e é essa obnubilação mesma que faz da cegueira a nossa natureza. Não é à toa, portanto, que traçamos esse primeiro elo, esse primeiro esboço de um arquipélago. Assim como Casares, Tirelli Neto parte do sentido da perda enquanto direção, projeto e significado, na medida em que, como nos escreve Casares, "Tudo está perdido: a vida com a mulher, a solidão passada" (Casares, 2016, p. 37) - para uma afirmação da perda do sentido. A voz do sujeito do poema, diante da ilha, retorna às lembranças, às memórias, revelando como esse retorno é desde já perdição. "Sempre que me vejo obrigado a retornar a esta casa também me vejo sozinho" (Tirelli Neto, 2015, p. 30). E mais adiante, escreve: "Logo ficamos tão sozinhos, tão separados quanto querem nossas lembranças" (Tirelli Neto, 2015, p. 31).

As lembranças são como territórios de pertencimento e apartados; não nos territorializam a não ser em nossas próprias imagens; não escolhem abrigar-nos, mas, sim, desalojar-nos em projeções, histórias, fabulações. Ainda que pareça nossa, essa terra nos engana. Desde o primeiro livro, Tirelli Neto investe nas múltiplas imagens do isolamento, mesmo que, a princípio, essas imagens viessem nubladas, como nos versos do primeiro poema de Synchronoscopio (2008), intitulado "Carta de intenção":

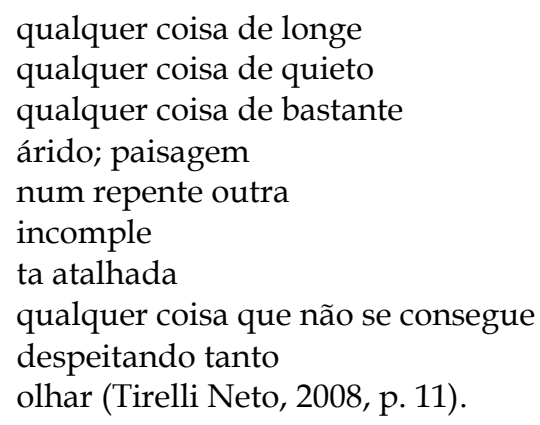

Podemos dizer que desta primeira publicação à ilha do terceiro livro publicado, alguns temas persistem, ainda que, como dissemos, a emergência muitas vezes é pouco nítida. Há desde já um prelúdio para o afogamento, exposto nos versos "em tocar tem uma encosta// paralém/ é mar aberto" (Tirelli Neto, 2008, p. 12). Ou ainda no poema sobre a aula de natação, em que o professor teima em chamar-lhe de Ismael. O motivo da água repete-se em "Angra I" e "Angra II", "La barca" e em "Inundação", quando se escreve sobre um sujeito que teria um "quê de coisa/ represada/ que se solta" (Tirelli Neto, 2008, p. 58) - como também essa primeira publicação, que acaba por realizar o movimento de algo há muito tempo contido. Por isso o nome próprio correto ainda não é registrado, erra-se na aula de natação, e as águas são o líquido da embriaguez e da ressaca que turvam as imagens. Ali o poeta se vê às voltas com a indefinição, como a própria epígrafe de Herberto Helder já anuncia, "E diziam: é o meu inferno, é o meu paraíso".

Entre a máquina que identifica o grau em que dois sistemas estão sincronizados e a ameaça da dessincronização dos ilhados, a ladainha de Ramerrão (2011) tenta, como um pombo correio, transpor distâncias, afinal "A vontade de pontes/ é apenas humana, mas/ para mestrar as/ medidas exatas, seria/ preciso antes terminar um livro/ romper com o diletantismo,/ morrer" (2011, p. 37-38). De fato, o poeta constrói uma ponte sem nunca deixar de avizinhar-se da água, do risco de afogamento, para aportar naquela ilha que, embora se faça chão, impõe outros desafios à paisagem e à sobrevivência. Há em Os ilhados um texto intitulado "Uma visita", no qual a irmã se lembra de ter de ficar "na ponta dos pés para enxergar a lagoa por essa janela" (2015, p. 30). O desejo de amplidão, de horizonte

\footnotetext{
${ }^{2}$ A expressão encontra-se na obra Em busca do real perdido, de Alain Badiou, para quem "o real é atingido não através do uso da formalizaçãojá que ele é justamente o impasse dela -, mas quando se explora aquilo que é impossível de formalização" (Badiou, 2017, p. 31).
} 
acarreta a morte, posto que a personagem desequilibra-se dessa mesma janela e cai "de uma altura muito grande" $(2015$, p. 32). Onde antes se abria uma visão panorâmica, hoje impõese o risco do detalhe aterrorizante. Àquele cenário anuviado de alguns poemas do primeiro e do segundo livro, sobrepõe-se a condição sombria das memórias e da particularidade centrípeta, hipnótica. Da janela indiscreta que não permite senão o foco voyeur.

Podemos dizer que a ilha representa esse desafio às fronteiras, ao pertencimento e à própria visualização do horizonte. Por isso, diante do que seria a impossibilidade formalizar a paisagem, visitar esse acesso implica sempre incorrer na possibilidade de um afogamento fatal. A água é tanto condição de vida quanto risco de morte. Sair da ilha é, portanto, uma promessa sem garantias. Como já diziam os versos de Ramerrão: "Tudo ia bem/ contanto que não se movesse" (Tirelli Neto, 2011, p. 43). Não nos é dada a apreensão, nem a possibilidade de movimentação. Paz descreve essa nossa condição, ao descrever a condição dos mexicanos:

Não suportamos a presença dos nossos companheiros. Fechados dentro de nós mesmos, quando não dilacerados e alienados, depuramos uma solidão sem referências a um além redentor ou a um aquém criador. Oscilamos entre a entrega e a reserva, entre o grito e o silêncio, entre a festa e o velório, sem que nos entreguemos nunca (Paz, 1950/1992, p. 61).

A nós nos é negado qualquer convívio pacífico, despretensioso. O próprio observar apresenta seus perigos. O narrador da novela de Casares, por exemplo, mesmo depois de tanto planejar sua aproximação de Faustine, não consegue se comunicar, tampouco é capaz de expulsar os intrusos da ilha. Não há chaves para onde faltam fechaduras. Na ilha de Morel, o observador mantém-se entre a observação desesperada das imagens e o desejo de se juntar a elas nessa confinação. No mesmo sentido, a máquina poética está sempre prestes a perder o fôlego e submergir. Como capturar esse trecho de terra que nos cabe, mas que está sempre em vias de se deslocar, de se retirar de nossa visão?

Como escreve Badiou, "só um ponto fora de formalização pode dar acesso ao real" (2017, p. 33). Em outro poema desse álbum de des-recordações de Tirelli Neto, intitulado "O meu namorado", descreve-se este, que "era muito bonito / lembrava //um boneco de cera / de algum cantor famoso" (Tirelli Neto, 2015, p. 53). Desde a primeira lembrança, o namorado parece já evocar a produção de uma memória fadada à cópia ou ao esquecimento, como uma segunda natureza ou uma obnubilação, reproduzindo a imagem de algo que nunca esteve ali, que sempre permaneceu fora de foco. Trata-se de uma espécie de simulacro, corpo tátil, mas que não se pode apreender. Mais adiante, lembra-se também dos hábitos criados com o relacionamento:

os meus amigos

nossos amigos

rumavam

depois do acidente

para a sala de estar

abriam uma garrafa de vinho

ligavam a tevê

na sessão de meia-noite

uma ginasta

soltava-se da barra

e partia-se ao meio

ao aterrissar

eu buscava a giros

cada vez mais bruscos do molinete

trazer de volta à enseada

os anos adiante (Tirelli Neto, 2015, p. 54). 
No man is an island porque o homem conta com a sua imaginação. Para além das quedas de alturas muito grandes, há também os saltos e os giros dados frente às lacunas entre o sujeito e os espaços que ele ocupa ou que se ocupam de sua memória. Alguma coisa do desgarrar-se das imagens faz a máquina funcionar à medida que ela não dá conta de agregar todas as imagens. Naquela sala de estar, em pedaços tal qual a ginasta que se quebra ao cair mal no chão, já se ansiava outro tempo. O sujeito se vê vendo-se como um corpo não presente. Trata-se de um deslocamento por memórias e lembranças, tempos e espaços, que trazem a imagem de um sujeito incontornavelmente desconjuntado de suas representações, de modo que a temporalidade parece corresponder a de um futuro anterior, no qual o sentido só se concretizaria retroativamente, como no texto "Dezesseis anos novamente" ou na dupla de poemas intitulados "As cidades antevistas", um situado no início da obra, outro no fim. Neste último, inclusive, diante do que ainda não se apresentava como à consciência de hoje, indaga-se: "que espécie de olhar teria sido suficiente?" (Tirelli Neto, 2015, p. 95).

Olhar o olhar que não vê, olhar o que na imagem não se encontra - o que uma ilha esconde? Quais são seus elos com o continente? Não sendo nunca suficiente olhar retroativamente, não tendo sido suficiente o olhar que se possuía na altura, nota-se que a visão é altamente parcial e que o acesso às imagens passadas (e às imagens que passam) são "Em tudo e por tudo trancado" (Tirelli Neto, 2015, p. 37). Ainda que essa concepção ecoe Lacan, para quem o real é sempre negado, há algo de contemporâneo no modo como essa negação é sentida na transformação dos espaços em pontos turísticos. Ainda em "As cidades antevistas", o poeta escreve: "Como não reparara ainda na enorme estátua de Gandhi? // Diz que é posta ali não é de ontem" (Tirelli Neto, 2015, p. 37). Antever a cidade onde se viveu implica sempre prever que ela nunca fora completamente vista? Desvemos o que teremos presumivelmente de rever? Como as cidades sobrepõem camadas que, por um istmo, relampejam a arquitetura que as sustentam?

Por um lapso do real, a estátua se apresenta sobejamente. Desconhecer o lugar de onde viemos nos possibilita, então, estranhar o mito de nossa origem, desconfiando daquilo que nos vê quando olhamos. Como exilado, ao qual é negada a permanência em suas cidades originárias, o olhar do poeta não reconhece mais o que encontra depois de tanto tempo. Ao revisitar os lugares do passado, reconhecendo-os como diferentes de si mesmo, tem-se também a impressão de que o corpo já não se movimenta nos lugares como antigamente. $\mathrm{O}$ corpo "está fora de proporção com relação ao mobiliário dessa casa" (Tirelli Neto, 2015, p. 30), onde se calcula mal a distância do beijo que faz o sujeito golpear a testa contra a torneira. As medidas e os modos de espaçar-se não são mais os mesmos que a memória lhe oferece - ela lhe prega peças, enganando àquele que se açoita no conhecido. Ao que o poeta lança a questão, em outro poema: "até que ponto conseguiremos chegar 'com nossos próprios pés'?" (Tirelli Neto, 2015, p. 17).

Os pés dos poemas são, portanto, variados; Tirelli Neto intercala poemas longos e curtos e poemas em prosa, testando de múltiplas maneiras conter (no duplo sentido, de receber e de impedir) os registros e os estímulos que o assolam. Assim, pôr-se à prova na linguagem provoca não só uma queda en abyme, um esbarro, um desconforto e uma inaptidão, como também um desencontro (consigo mesmo, através das discrepâncias do que o olha naquilo que se vê, e com aqueles que se lhe apresentam). Desencontro que é favorecido sobremaneira pelo poema em versos, ou pelas quebras na prosa, haja vista a desconexão de que é feita, de "uma não coincidência e [de] uma desconexão entre o ritmo sonoro e o sentido", como se "a poesia vivesse [...] apenas da sua íntima discórdia" (Agamben, 2012, p. 31). Em Jean-Luc Nancy, essa mesma percepção gera a seguinte definição: "a própria poesia pode muito bem se encontrar lá onde não há mesmo poesia. Ela pode mesmo ser o contrário ou a recusa da poesia, e de toda poesia" (Nancy, 2016a, p. 146). Se, na memória, a voz não se encontra em sua origem, mas em seu devir, tampouco a poesia se realiza como cena da origem, apenas como experiência privilegiada das distâncias das imagens que se veem e que são vistas.

Se a estátua de Gandhi oferece-se como enigma por ter estado sempre no mesmo lugar sem nunca ter sido notada, os senhores do poema "O homem sobrescrito" já não ofertam nada de desconhecido: "Ora, os senhores nunca têm nada de muito esfíngico a dizer quando venho pedir ajuda para o aluguel, tão logo dobro a esquina improvisam meu antigo quarto em 
oratório" (Tirelli Neto, 2015, p. 75). A ilha se torna um amontoado de ocupações indesejadas. Ao passo que nesse poema o antigo quarto é desocupado e passa a ser utilizado com outras funções, no texto "As mães em chama", a visita toma conta de toda a paisagem, impedindo que outras imagens sejam criadas. E essa mãe, "a quem se ateou fogo" (Tirelli Neto, 2015, p. 77), não deixa nunca de se consumir, de consumir os afetos, de se alastrar para além do apartamento, nos recônditos da memória, nos vãos que antes lhe eram negados.

Às vezes o homem quer ser uma ilha e não consegue. As vozes e imagens não se distanciam, elas pesam, pressionam, sobrecarregam. "Começará uma história íngreme" (Tirelli Neto, 2015, p. 48), alerta o poema. O que é pendente, o que se arrisca a todo momento na verticalidade, forma uma espécie de história concêntrica, natureza não escolhida da lembrança. Nunca temos liberdade de decisão sobre o que vamos lembrar ou esquecer. Por isso, para recordar, é preciso antes que se saiba o idioma falado na altura, e a essa tarefa o poeta não se dedica em "Ilegibilidade II" sem contar com a alegria do erro. À aprendizagem da lembrança impõe-se a necessidade de se reaver com a ilegibilidade, ponderando sempre entre o que é significativo e o que é insignificante lembrar. Nas aulas de língua estrangeira, a crítica à inocência e ao automatismo do método se nota no seguinte momento: "Não era tão mau professor, contudo, ignorava - uma emergência pode e frequentemente tomará sobre si termos os mais imprevisíveis" (Tirelli Neto, 2015, p. 48).

Tateando os espaços da memória, o poeta tateia também o espaço da linguagem, os arcaísmos e as expressões corriqueiras sobre os quais seus poemas se constroem, em uma espécie de diálogo e cruzamento entre tempos: "bom, sejamos francos" (Tirelli Neto, 2015, p. 11), "pois bem, pois bem" (Tirelli Neto, 2015, p. 913), "quem em sã consciência" (Tirelli Neto, 2015, p. 53) "e o senhor certamente convirá" (Tirelli Neto, 2015, p. 72). Esses são exemplos de expressões que pressupõem uma compreensão, que interrompem as explicações para garantir que o leitor ou o interlocutor o estão acompanhando em sua explanação. No entanto, não há nada garantido: nem na memória, nem no entendimento. Não sabemos tampouco que aquele que o escuta está ciente das convenções (linguísticas, culturais, rítmicas) que se estabelecem em seus poemas. O imprevisível responde tanto pelo uso dessas expressões quanto por aquilo que não se pode domar em relação às suas efetividades.

Inclusive, em "sob uma marquise, 26 de outubro de 2014", escrito sobre a extinção das videolocadoras, o poeta se pergunta: "Haverá tempo ainda", ao que mais à frente responde: "Já não há tempo, / afinal" (Tirelli Neto, 2015, p. 66). Se o tempo já não é mais o mesmo que aquele da locação de filmes, de uma cultura cinéfila baseada no contrato de um aluguel, o tempo do poema é o tempo de salvar tais gestos, a figura dos "funcionários / das videolocadoras / sua beleza sem vigor, seu imperioso tédio / sua juventude - sempre truncada - sempre truncada" (Tirelli Neto, 2015, p. 66). Ainda assim, ao assinalar a data, circunscrevendo o desaparecimento desse tipo de serviço, sua voz salva benjaminianamente os objetos e os hábitos do passado na escrita, salvando "também esta", suas existências de papel:

Coloquemos diante da história uma pequena pena de videolocadoras

Coloquemos diante da história também esta pequena pena de videolocadoras

Rápido, não há tempo de explicar aos pósteros

(o que são invólucros do meu tempo? O que é este objeto negro, cassete na clareira?)

(Tirelli Neto, 2015, p. 67)

O poeta enfrenta a linguagem dos "leks", com outra linguagem, elegante, sinuosa, dialógica, uma linguagem menos rápida, disposta a "acomodar/ o ar, a luz" (Tirelli Neto, 2015, p. 69), "aguardando com perfeita paciência / o momento da fábula" (Tirelli Neto, 2015, p. 71). Diante de uma linguagem pura imagem, inespecífica, uma linguagem que dê a ver objetos que não estão ali, que foram excluídos do campo, aquilo que não tem (mais) lugar a não ser no poema. Assim, vê-se melhor o alheamento ao confrontar as dicções, avizinhando os ídolos do contemporâneo aos pequenos fatos e marcas de outros tempos, imaginados, recordados, inventariados.

Por isso, ainda que esse avizinhamento insinue diálogos, confabulações, digressões, a correspondência em Os ilhados não deixa de ser uma autocorrespondência com vistas à autopreservação. No texto "Desespero", o poeta descreve os amigos "que vivem em edículas 
sob o sol do meio-dia", aqueles que "vão para dentro, sombras que se recolhessem ao interior dos objetos", e diz que são eles que "aprenderam a correspondência consigo próprios" (Tirelli Neto, 2015, p. 93). Como previram os teóricos latino-americanos, ainda que o mundo se globalize, nosso território está fadado a se ver sempre como uma ilha, na qual não há espaço comum, na qual a partilha está interditada. Nossos afetos nos cercam de todos os lados. Afinal, "a vida tornou-se exatamente aquilo que mais temíamos" (Tirelli Neto, 2015, p. 93), um contrafeitiço. Poder revê-la retroativamente, como no filme A espuma dos dias, de Michel Gondry, nos faz perceber seu apequenamento, nosso aprisionamento: "Algo que já amamos, / algo / que certamente já foi amado / por nós, começa / a estreitar a casa /depois do anoitecer, /coloca seus ângulos /em causa" (Tirelli Neto, 2015, p. 50).

\section{Caso postal}

Se nunca saímos das ilhas, se como solitários procuramos afixar-nos diante da desorientação que nos acompanha, se as ilhas acabam por nos fazer reconsiderar o limite que separa a salvação do afogamento, uma opção é tentar ultrapassar essas barreiras (imaginárias, traumáticas, geográficas) em cartas, como o faz Tirelli Neto no livro seguinte, Os postais catastróficos, lançado em 2018. Neste, o poeta dedica-se a inventariar os "objetos negros" que não existem mais, tal qual as videolocadoras da obra anterior, assim como a narrar uma espécie de diáspora extática, que já estava posto de algum modo em Os ilhados, quando o poeta escreve: "tentar tornar o exílio em // método" (2015, p. 41). Neste, é hora de afirmar: "Parado e diaspórico estou posto à janela" (2018c, p. 25). Ou ainda: "Não emigrar do meu roupão" (2018c, p. 26). Os postais nem sempre serão de cidades visitadas, mas de lugares desabitados, de regiões domésticas, de memórias criadas assim, o sujeito permanece para sempre estrangeiro em sua própria ilha.

A rigor, exílio e extinção não são topos exclusivos de sua poesia. Para aquela saída da poesia que Jean-Marie Gleize reivindicou em seu Sorties, com ecos na antipoesia, na apoesia ou no lirismo crítico de poetas latino-americanos como Nicanor Parra, há outros tantos projetos que nem sempre consentem com a exclusão do verso ou da subjetividade. Marília Garcia, por exemplo, aposta em seu engano geográfico, numa espécie de cruzamento entre poesia e narratividade, "ponto de tensão de uma cartografia do espaço intervalar entre seres e coisas" (Garramuño, 2016, p. 13). Para a crítica Florencia Garramuño, é possível dizer de uma produção contemporânea que visa ter lugar no impróprio, a buscar os próprios confins da dicção poética:

É por isso que essa ideia de poesia como limiar, como confim, pode abranger também outras formas que no espaço entre o impessoal e o pessoal incorpora vozes heterogêneas, corais, a incorporação da narratividade, a expansão do verso e sobretudo também a emergência de outras formas textuais contemporâneas que muitas vezes podem ser pensadas tanto dentro do âmbito da poesia como no da prosa (Garramuño, 2016, p. 16).

No caso de Tirelli Neto, prosa e poesia se intercalam nos enganos geográficos da memória, do afeto, do diálogo. "Partir ou ficar eram um mesmo lugar sem matizes" (Tirelli Neto, 2015, p. 28), escreve o poeta dando a ver que é a linguagem que tenta sutilizar as diferenças, trabalhando também pelas conformações entre a experiência e a dicção. Assim, é possível habitar a catástrofe, rodeá-la, circunscrevê-la, se for possível torná-la dizível, pensável, sensível. No poema "Caso postal", senta-se em um local que dobra a imagem retratada no papel, e observa-se que apesar das "Centenárias construções abrigando / Agências de contabilidade, escritórios de advocacia" (Tirelli Neto, 2018c, p. 12), há um fluxo que conduz o sujeito "A empórios / Lojas de souvenir / Balcões onde se negociam - som, fúria - passeios de escuna" (Tirelli Neto, 2018c, p. 12). A imagem figurada se distancia da imagem observada a olho nu, assim como "Ao escrever / A muque admito que estamos distantes" (Tirelli Neto, 2018c, p. 12), e na paisagem, há correntes "que apartam aquilo que é propriamente histórico / De tudo" (Tirelli Neto, 2018c, p. 13). O olho crítico, mais uma vez, procura aquilo que está fora do campo de visão.

À medida que os postais diferenciam as camadas da cidade e o olhar seleciona os focos e as projeções, o verso trabalha na tensão entre o relato e a poesia. Se podemos perceber o poema contemporâneo brasileiro mais próximo de uma diç̧ão prosaica, íntimo portanto da própria cena 
enunciativa, é porque há algo desse movimento diegético que tem mais a dizer no poema do que a qualidade mimética. Os postais, nesse sentido, não exatamente se referem àquilo que se vê, mas trazem o visto para o dizer, de modo que a sua existência coincide apenas com a fala, com o ato de suscitá-lo na palavra. De acordo com Nancy, é isso mesmo que distingue a diegese: "o relato faz acontecer isto: que nada acontece sem relato" (Nancy, 2016b, p. 76). Relatar é, portanto, reconhecer que haverá sempre um outro inapreensível, irrepresentável, perdido; e a fala que dessa condição emerge será uma alegoria daquilo que, na palavra, encontra uma maneira de recomeçar. A partir da afinidade entre relatar e recitar, o filósofo postula:

Os nomes que o recitante chama a comparecer são seus próprios nomes - seus nomes próprios jamais inteiramente apropriados, em sua não-significância, a essa propriedade insigne, inominável, que forma a verdade do que acontece [arrive], a verdade de sua chegada [arrivée], a verdade da história contada, recitada, verdade chamada, invocada, evocada, inverificável, ela mesma errática e espalhada por toda parte no relato, tecendo o próprio relato sem nem se mostrar senão pela arte do recitante (Nancy, 2016b, p. 78).

Assim, o relato se endereça, se dirige, convoca. Recita nomes. Assina. Certo é que esse endereçamento já se nota na poesia brasileira moderna de maneira tão marcada ao menos desde Ana Cristina César - como bem observara Silviano Santigo em "Singular e anônimo"; Flora Sussekind, em Até segunda ordem não me risque nada; ou, mais recentemente, Marcos Siscar, em "Ana C. aos pés da letra". De modo geral, podemos dizer que, se por um lado, sua escrita investe em características íntimas, por outro, assume-se como correspondência, inviabilizando qualquer oposição simplista entre essas duas qualidades. Algo da experiência do ilhamento já solicita a escrita postal, mesmo que o conceito de mediação, notável, por exemplo, no uso da carta endereçada, acabe por ser posto em questão, na medida em que nesse papel escreve-se sobre ele mesmo. Ainda que se destine um postal a alguém, o cartão agrupa em seu destino todas as pessoas que o atravessam, posto que, invariavelmente, essa escrita íntima está exposta como nenhuma outra, sem envelope.

No intuito de aproximar, na promessa de que haja sempre alguém a escutar, o relato torna sensível a distância e a ausência. Escrever um postal não apenas notabiliza os deslocamentos, desterritorializando a paisagem em direção àqueles que não podem vê-la, como provoca desagregações de outras ordens diante do que se apresenta fantasmagoricamente fragmentado. Em um dos primeiros momentos da obra, afirma-se: "VAMOS/ há mais vazio para ver // há mais / vulnerados castelos / interiores,// exteriores, / não se percebe // diferença" (Tirelli Neto, 2018c, p. 16). O passeio turístico se destina a apresentar não as construções, mas a indiferença entre os vazios e os castelos. Os espaços que dão lugar ao eco. Em outro poema se diz: "Sons de construção ao longe / Em nada diferem dos sons de demolição" (Tirelli Neto, 2018c, p. 45). Há um movimento que tenta tornar indiferente o construir e o destruir, enquanto o poema trabalha para mostrar as diferenças.

Em um ensaio publicado no Suplemento Pernambuco, nomeado "Discurso do poeta calejado de começos", o escritor ressalva a importância da poesia em nos habituar ao tempo específico dos processos, de modo que colocássemos em suspensão a própria noção de produção. Afinal, não seria a soberania da produção o que nos obscurece as singularidades do tempo que constrói do tempo que destrói?

Seria preciso internar-se no tempo para ver: os elementos se unindo, se encadeando, conformando já o próximo choque e o próximo silêncio. O que se pode fazer, no entanto, com esse interdito? Com essa impossibilidade de internar-se no tempo? Que produção? Fazer poesia, trabalhar com poesia, talvez seja uma maneira de tentar alargar a noção desesperadoramente estreita que se tem hoje em dia de "produção", ou pelo menos de tentar apaziguá-la (Tirelli Neto, 2017, p. 3).

Como tornar sensível não o salto, nem a queda, mas todo o processo intervalar, contínuo? No "Postal do Olimpo", os primeiros versos dizem: "Ausência acorda / Luminosa, seguida / Ausência remira" (Tirelli Neto, 2018c, p. 21). Diante da imponência do monte, a paciência de instalar-se no tempo para ver o que está entre a altura e a ruína, a nobreza e a escravidão sobrepostas nas camadas do templo. Se aos deuses olímpicos eram dadas as montanhas para 
que dela fizessem seus tronos, o que se pode observar em tamanha altura é a quantidade de esforços sobre-humanos ou desumanos necessários para compor as imagens míticas e os excessos divinos. Assim se movem os postais, atestando a distância entre a exibição do esplendor e a constatação do que hoje é apenas resto, vestígio, selo sem destinatário certo.

Mudam-se os tempos, mudam-se os olhares. Instalar-se no tempo para ver o vazio é também poder alcançar o vazio da linguagem. São marcas desse processo de "internar-se no tempo", o uso de vocábulos arcaicos, como já se notava em expressões de Os ilhados, mas agora com o sentido de criar uma tessitura antiga, a exemplo dos termos "casario", "tafetá", "musselina", "andaço", "remira", com os quais o próprio sujeito se revolve. Em outro texto publicado no Suplemento Pernambuco, sobre as mudanças de cidade - Rio de Janeiro, Curitiba e São Paulo -, em dado momento o poeta escreve:

Aceno uma palavra velha, palavra de antiquário. Aceno uma palavra embolorada. Nenhum esforço para torná-la atraente ao público jovem. Adeus, envelheço com ele, emboloro com ele, misturo-me à cacarecada. Posto no mundo para ser derrubado pelos elefantes (Tirelli Neto, 2018, p. 24).

Se as mudanças anunciam-se nas camadas da cidade, anunciam-se também na linguagem, mas agora como decisão do poeta por esse outro léxico, assumindo uma posição diante da história, mas também diante dos sujeitos históricos, dos lugares com dimensão e profundidade históricas. Como dissemos, trata-se de criar uma linguagem fora do campo, um segredo que dê a ver não apenas essa existência exilada, mas também o limite que separa a inclusão da exclusão. "Me desobrigar em definitivo de um mundo que está seguramente indo para o Diabo" (Tirelli Neto, 2018c, p. 26), sustenta. Misturando-se à cacarecada, o poeta se obriga a pensar e acolher o que retorna, o que não deixa de passar, assim como também se refugia naquele passado nunca inteiramente vivenciado.

Sua atenção à linguagem é, portanto, uma obrigação para com a ladainha, esta palavra capaz de fazer durar um único tema, desdobrando-o. De alguma maneira, esses arcaísmos são também fortalezas em ruínas, restos imaginados do Olimpo, elegâncias em torno das quais o poeta ergue seus poemas com apuro, evidenciando que é preciso não apenas repensar os movimentos das cidades, mas os movimentos da língua que dão a ver as mudanças de foco, de captura, de enquadramento. Ao gosto de um garimpeiro, em busca não só de pérolas linguísticas, mas também de objetos complexos ou de objetos que se tornam complexos na literatura, como nos diz o poema de Os postais catastróficos: "devo ter portanto uma relação visceral / com a literatura / ela torna a vida difícil / ela invertebra ela", ao que mais adiante adiciona: "acredito / nos instrumentos preensores, gélidos, escaldantes" (Tirelli Neto, 2018c, p. 20).

É certo que a publicação dessa obra, no ano de 2018, reage também à série de catástrofes as quais nosso contexto engendra. O primeiro poema já denuncia o estado doentio do que se apresenta: "Encher uma página com este hospital. / É nisto que devo me aplicar / / Cada verso um leito" (Tirelli Neto, 2018c, p. 9). A força dos acontecimentos, das notícias, das tragédias, não mais viabiliza aquela distância, tampouco a instalação para ver. "(Aderidos ao que ocorre)" (Tirelli Neto, 2018c, p. 9), escreve o poeta, não nos sobra uma lacuna através da qual elaboramos uma perspectiva crítica sobre os fatos. "Fracionamos o verbo / 'olhar' em muitos outros. Ato biombo do olhar" (Tirelli Neto, 2018c, p. 9). Sem o que se ausenta do campo de visão, corroboramos qualquer enquadramento que se nos apresenta dos fatos.

No poema "Scenas da actualidade", em que se joga com o arcaísmo e com o anacronismo desde o título, o poeta começa situando essa atualidade: "Sim foi no ano dos linchamentos" (Tirelli Neto, 2018c, p. 35), sem dizer com toda clareza que esse pode ser o ano presente, ou qualquer um dos últimos anos. Esses atos de punição sem julgamento não deixam de ser sintomas daquela distância impossível, daquela aderência compulsória aos acontecimentos, que nos levam mais uma vez à morte, à extinção, ao "ato biombo do olhar". Esse mesmo contexto nos é apresentado a partir de outras caracterizações, como o "Ano de invasões", "O ano / em que voltamos a sofrer como poetas", "O ano / em que as estrelas baixaram / dos túmulos", 
"Ano / de constelações rearranjadas a todo o pano", para finalizar sentencialmente nos últimos versos: "O ano em que descobrimos / que o perdão era impossível" (Tirelli Neto, 2018c, p. 35).

$\mathrm{Na}$ ordem dos acontecimentos do dia, a poesia de Tirelli Neto cria mais uma nuance daquela espécie de força maior já presente em seu Os ilhados. Algo está sempre retornando, impondo sua resistência em passar, seja na insistência das figuras da mãe e da irmã, seja na impossibilidade do perdão em permitir o esquecimento. Se o coletivo está sempre de algum modo em suspeição, isso que não deixa de assumir sua voz, sua imagem, sua presença acaba por tornar-se o relato possível diante dos impasses de formalização e dos dilemas da narração poética. Para quem escrevemos nossos postais? Quais paisagens queremos acessar? O poeta se dirige a alguém, quando usa a primeira pessoa do plural ou a segunda do singular, trazendo o "você" para o poema-postal, de modo a torná-lo cúmplice de seus dilemas. Há, ainda que sutilmente, um falar do outro falando-lhe, um apelo no endereçamento, uma demanda, um desejo de que o sentido (espacial e semântico) seja tomado tanto como envio quanto como desvio. Não no sentido de uma retirada da cena, mas na produção de uma perspectiva outra, sobre outra distância, para esse mesmo apelo que, em certa medida, torna a todos coautores da mensagem.

\section{O que pretende a expressão tudo no lugar}

De maneira geral, a obra de Tirelli Neto nos oferece uma experiência singularíssima das implicações desse tempo particular que se faz espaço complexo, na medida em que tanto a poesia quanto a prosa questionam seus trabalhos específicos com o espaçamento. O verso e a subjetividade do poeta não se isolam pacificamente. A ilha jamais será um lugar de apaziguamento. Podemos escrever postais, mas jamais levianamente. Há toda uma tensão entre as vozes que a habitam e aquelas às quais a cena se dirige, seja na forma do endereçamento, do diálogo ou da simples referência, como é típico de sua escrita citar nomes de conhecidos e desconhecidos, apostando na tensão entre o reconhecimento e a apresentação, como é o caso da estrela crepuscular Buster Keaton. A elas, o poeta se mistura não para perder a sua voz, tampouco para exibi-la, mas para tornar-se irreconhecível entre tantos personagens incógnitos. Assim, se desenha aquele espaço intervalar de que fala Garramuño, e que está sempre em vias de recolocar-se imprevisivelmente.

No último livro publicado, A mais ou menos completa ausência, o primeiro conto, intitulado "Um mito de origem", cria uma ambiência em torno de um vazio suscitado pela mudança de uma vizinha. "Os demais moradores do andar - por que não dizer do edifício inteiro resumiam-se a uma banal fantasmagoria de passos, portas batidas, pancadas ondeantes no encanamento. Decerto, havia entre nós mais eco que som" (Tirelli Neto, 2018a, p. 7), escreve. Porque não há o que explorar internamente, o narrador parte para os quarteirões, para as ruas do bairro. A vivência nesse vazio habitado por fantasmas, tal qual a ilha de Morel, faz o narrador imaginar-se como o Primeiro Homem, "instado a se pronunciar, pelo menos. / O Primeiro Homem a não ter o que dizer" (Tirelli Neto, 2018a, p. 9). Se os narradores, conforme Walter Benjamin, respondiam pelo viajante ou pelo sábio, dois modos de conhecer histórias, aqui, o Primeiro Homem, no primeiro conto, abandonado à sua solidão de ecos, representa contraditoriamente o interdito da narração. $\mathrm{O}$ fato de a palavra pressupor que há sempre algo para se dizer abstrai a condição de ter alguém para quem dizer.

Por isso, o interlocutor de Tirelli Neto não será nunca qualquer um (ainda que também não possa ser alguém determinado), e também não será ninguém. Entre a elasticidade do mito (e da própria palavra como mito de comunicação) e o mito como interdição à interpretação, a especificidade de seu uso, de seu contexto, dos agentes envolvidos. Mais do que uma impessoalidade ou um esvaziamento, trata-se de, pelo uso pessoal, reafirmar a importância da singularidade, considerando, para tal, aquele que lhe lê, que lhe ouve, que se demora em sua ladainha. O poeta aposta em colocar diante da visão o que está fora dela, nós, o ponto fora de foco, contrapondo o que pertence à cena ao que se exila, ao que se exclui. Isso não significa, no entanto, que, por firmar-se nas suas propriedades particulares, a obra assenta em noções de pertencimento ou de identificação. Como mostramos, a voz, apesar de estar à 
deriva, em busca de lugares e de imagens de lugares, encontra-se muito bem delimitada pela linguagem de que se vale, na tentativa de aliar mais precisamente palavra e impressão de mundo. Quando se refere às águas, há qualquer coisa de muito direto: "Assim a noite recua, deixando sobre a enseada seus corpos" (Tirelli Neto, 2018a, p. 43).

Partindo rumo aos confins do léxico e da sintaxe, altamente elaborados, o poeta parte rumo aos confins do contemporâneo, ou aos seus estratos fossoriais, para usar um termo seu, para recompor o cenário. O confim, nesse caso, não é a confirmação de um final, mas de uma força que está sempre investindo contra a lembrança, contra os afetos, contra a vida. Dessa última obra, inclusive, narrando sobre o cinema de repertório do antigo Odeon, o poeta escreve: "'a distância é a única coisa no mundo que é consistentemente nova', que vai se renovando o tempo inteiro, e vai calcando muito bem cada sílaba do advérbio 'consistentemente'" (Tirelli Neto, 2018a, p. 11). Diante de um tempo tão pouco distanciado dos acontecimentos, tão aderido acriticamente aos fatos, o que nos leva às acusações e aos linchamentos, ler Ismar Tirelli Neto nos faz levantar a cabeça, como diria Barthes, para tomar distância não só daquilo que, com a devida atenção, lemos em suas obras, mas também para refletir sobre a própria distância, sobre o que ainda encadeia nossas palavras às coisas, sobre o que nos liga à tela do tempo. Narrar, hoje, não implica necessariamente negociar com os desacordos, com os dissensos, com a incomunicabilidade? Como viver junto seria possível?

Se não é possível pensar sua literatura em um mesmo nível de uma literatura do exílio stricto sensu, haja vista que seu deslocamento não é motivado pelas mesmas razões políticas, econômicas e sociais de refugiados, as implicações éticas e estéticas de sua obra acabam por contribuir para a reflexão disposta a entender a condição do sujeito contemporâneo fora de lugar. Ao mesmo tempo, a tradução por Tirelli Neto de obras como Lá não existe lá, sobre índios urbanos no estado da Califórnia, que mescla questões como violência e identidade, família e pertencimento, revela-nos como suas escolhas e leituras também são atravessadas por questões em comum postas na obra própria. Afinal, o discurso da origem não é um discurso mítico, cuja finalidade tem mais a ver com a instauração do que com a confirmação de algo que já estava lá? Ainda que muito dos processos de aculturação, de assimilação e de globalização não possam ser interrompidos, a ponto de retomarmos os ritos que nos fundaram, é preciso dizer que, instalar-se no tempo, demorar-se nas palavras, acaba por abrir espaço para que se reflita com a devida atenção os processos que de alguma maneira insinuam-se como fronteira, encerramento, fenecimento, desaparecimento.

Se lá não existe lá é porque o aqui, independente de nossa localização, nos alcança e nos interpela inapelavelmente. A coincidência, como lemos no conto "Joaquim", não pode ser senão o encontro de desconhecidos que ignoram não se conhecerem. $\mathrm{O}$ reinventar da distância, jamais deixado de lado por tempo ou contexto algum, não garante que concordemos, que os atos e os seus efeitos correspondam e identifiquem-se, mas, mesmo assim, a palavra ou a imagem possuem maneiras de nos deslocar e nos situar empaticamente ou no âmbito da imaginação. Elas fazem com que nos encontremos, todos nós que não conhecemos. A própria experiência do espaço nos afirma que, mesmo que a presença dos sujeitos seja irregular, sem medida, imprevisível, o acaso de algum modo opera ainda que seja em oposição a. Isso aprendemos quando lemos:

Já não é possível dar um passeio descomprometido. Já não é possível ter as duas pernas boas. Já não é possível conhecer outras cidades. Já não é possível ter um mesmo amigo a quem telefonar aos domingos. Já não é possível viver na iminência constante de um poema, de um relato. Já não é possível relatar, já não é suficientemente possível. Já não é possível amar a quem já se anuncia, de partida, texto. Já não é possível fingir que não estamos escrevendo. Já não é possível ignorar que todos sabem disso, e que uma força muito potente nos impele continuamente de volta ao relato, talvez o cansaço. E já não é possível descansar. Já não é possível fingir que o vivo relato é possível. Já não é possível escrever como se não existissem gifs animados. Já não é possível ter as duas pernas boas. Já não é possível voltar, já não é possível começar tudo de novo, dessa vez com um pseudônimo (Tirelli Neto, 2018b, p. 90). 
Mesmo que nosso olhar possua limitações, tenta-se vencer as barreiras. Mesmo assim escreve-se. Mesmo que o espaço comprima-se, reduza-se ao limite de uma ilha, mesmo que o caminhar seja amparado, amputadas as pernas. Algo (ainda) nos move, nos direciona à palavra, desloca nosso olhar, mesmo que não se trate de um romance. A aventura agora é atravessada não exatamente pelo descobrimento, pela errância, mas mais precisamente pela sobrevivência diante da (e motivada pela) ameaça fatal. "O que não compreendo na história de Crusoé é o irrequieto do sangue. É isto que, em última análise, não consigo ler. Como pode ter conservado intacto o sentido de aventura em face de tantos sinais, tantos episódios beirando pela desgraça?" (Tirelli Neto, 2018a, p. 96).

\section{Referências}

ADORNO, Theodor W. (2003). Palestra sobre lírica e sociedade. In: ADORNO, Theodor W. Notas de literatura I. Tradução e apresentação de Jorge M. B. de Almeida. São Paulo: Duas Cidades; Editora 34. p. 65-89.

AGAMBEN, Giorgio (2007). Estâncias: a palavra e o fantasma na cultura ocidental. Tradução de Selvino José Assman. Belo Horizonte: Editora UFMG.

AGAMBEN, Giorgio (2012). Ideia da prosa. Tradução de João Barrento. Belo Horizonte: Autêntica.

ANTELO, Raúl (2016). A poesia não pensa (ainda). In: SCRAMIN, Susana (Org.). Alteridades na poesia: riscos, aberturas, sobrevivências. São Paulo: Iluminuras. p. 91-155.

BADIOU, Alain (2017). Em busca do real perdido. Tradução de Fernando Scheibe. Belo Horizonte: Autêntica.

CASARES, Adolfo Bioy (1936/2016). A invenção de Morel. Tradução de Sérgio Molina. São Paulo: Biblioteca Azul.

GARCIA, Marília (2012). Engano geográfico. Rio de Janeiro: 7Letras.

GARRAMUÕ, Florencia (2016). A poesia contemporânea como confim. In: SCRAMIN, Susana; SISCAR, Marcos; PUCHEU, Alberto (Org.). Linhas de fuga: poesia, modernidade e contemporaneidade. São Paulo: Iluminuras. p. 11-17.

NANCY, Jean-Luc (2016a). Fazer, a poesia. Demanda. Tradução de João Camillo Penna, Eclair Antonio Almeida Filho, Dirlenvalder do Nascimento Loyolla. Florianópolis: Ed. UFSC; Chapecó: Argos. p. 145-151.

NANCY, Jean-Luc (2016b). Relato, recitação, recitativo. In: NANCY, Jean-Luc. Demanda: literatura e filosofia. Seleção e edição de Ginette Michaud. Tradução de João Camillo Penna, Eclair Antonio Almeida Filho, Dirlenvalder do Nascimento Loyolla. Florianópolis: Ed. UFSC; Chapecó: Argos. p. 65-84.

PAZ, Octavio (1950/1992). O labirinto da solidão e post scriptum. Tradução de Eliane Zagury. São Paulo: Paz e Terra.

TIRELLI NETO, Ismar (2008). Synchronoscopio. Rio de Janeiro: 7Letras.

TIRELLI NETO, Ismar (2011). Ramerrão. Rio de Janeiro: 7Letras.

TIRELLI NETO, Ismar (2015). Os ilhados. Rio de Janeiro: 7Letras.

TIRELLI NETO, Ismar (2017). Discurso do poeta calejado de começos. Suplemento Pernambuco, Recife, $\mathrm{n}$. 136, p. 3. Disponível em: https:// bit.ly/2mm5LwK. Acesso em: 27 fev. 2019.

TIRELLI NETO, Ismar (2018a). A mais ou menos completa ausência. Curitiba: Ó Editorial.

TIRELLI NETO, Ismar (2018b). Acenando. Suplemento Pernambuco, Recife, n. 152, p. 24-27. Disponível em: https:// bit.ly/2kxe3By. Acesso em: 27 fev. 2019.

TIRELLI NETO, Ismar (2018c). Os postais catastróficos. Rio de Janeiro: 7Letras. 